\title{
Seroprevalence and spatial distribution dynamics of Yersinia pestis antibodies in dogs and cats from plague foci in the State of Ceará, Northeastern Brazil
}

\author{
Larissa Leão Ferrer de Sousa ${ }^{[1],[2], ~ C a r l o s ~ H e n r i q u e ~ M o r a i s ~ d e ~ A l e n c a r ~}{ }^{[2]}$, \\ Alzira Maria Paiva de Almeida ${ }^{[3]}$ and Luciano Pamplona de Góes Cavalcanti ${ }^{[2]}$
}

\author{
[1]. Secretaria da Saúde do Estado do Ceará, Fortaleza, CE, Brasil. \\ [2]. Departamento de Saúde Comunitária, Universidade Federal do Ceará, Fortaleza, CE, Brasil. \\ [3]. Centro de Pesquisa Aggeu Magalhães, Fundação Oswaldo Cruz, Recife, PE, Brasil.
}

\begin{abstract}
Introduction: In Brazil, the plague is established in several foci located mainly in the northeastern part of the country, where it alternates between active and quiescent periods. These foci in the State of Ceará have high epidemiological importance. In addition to other plague detection activities, plague areas can be monitored through serological surveys of dogs and cats (domestic carnivores), which, following feeding on plague-infected rodents, can develop mild to severe forms of the disease and produce long-lasting antibodies. This study aimed to characterize the circulation dynamics and spatial distribution of Yersinia pestis antibodies in dogs and cats in plague foci areas of Ceará. Methods: An ecological study was conducted to analyze the temporal series and spatial distribution of secondary data obtained from domestic carnivore serum surveillance in Ceará's plague areas from 1990 to 2014. Results: Joinpoint analysis revealed that the overall trend was a reduction in antibody-positive animals. The mean proportion of antibody-positivity during the whole study period was $1.5 \%(3,023 / 203,311)$ for dogs, and $0.7 \%$ $(426 / 61,135)$ for cats, with more than $4 \%$ antibody-positivity in dogs in 1997 and 2002. Antibody titers ranging from 1/16 to $1 / 64$ were frequent. Despite fluctuations and a significant reduction, in recent years, there were antibody-positive animals annually throughout the study period, and the localities containing antibody-positive animals increased in number. Conclusion: Yersinia pestis is actively circulating in the study areas, posing a danger to the human population.
\end{abstract}

Keywords: Yersinia pestis. Domestic carnivores. Reservoirs. Time series. Surveillance.

\section{INTRODUCTION}

The plague is a vector-borne disease found primarily in wild rodents, which can affect humans and other mammals, such as wild or domestic carnivores. Plague persists in natural foci in many countries worldwide. As yet, the accumulated technological advances and scientific knowledge have not been enough to eradicate $\mathrm{it}^{1,2}$. Human cases of the disease are recorded annually in several countries in Africa, Asia, and the Americas ${ }^{3}$.

Currently, the plague is considered a reemerging disease by the World Health Organization (WHO), with a tendency to increase in case number and geographical dispersion ${ }^{4}$. The plague can spread quickly, significantly impacting public health. Pneumonic plague can generate an international public health emergency, thus requiring WHO notification in accordance with current International Health Regulations ${ }^{5}$.

Corresponding author: Dra. Alzira Almeida.

e-mail: aalmeida@cpqam.fiocruz.br

Received 31 July 2017

Accepted 13 December 2017
Introduced to Brazil in 1899, the infection was established in several natural foci, and spread throughout the States of Piauí, Ceará, Rio Grande do Norte, Paraíba, Pernambuco, Alagoas, Bahia, Minas Gerais, and Rio de Janeiro. The zoonosis remains in these foci, alternating between quiescent periods and epizootics, a phenomenon expressed by high rodent mortality and sporadic human cases ${ }^{6}$.

Until the 1970s, human plague notification numbers in Brazil varied from 20 to 100 cases per year. Since 1990, human plague cases have been rare and sporadic. In the State of Ceará, Northeastern Brazil, the last laboratory-confirmed human cases occurred in the 1990s, with the exception of one case in 2005, which was initially misdiagnosed as dengue ${ }^{7}$.

Brazilian focal plague areas are continuously monitored through serological surveys of domestic carnivores [dogs (Canis lupus familiaris) and cats (Felis catus)], and the serological analyses are performed at the Central Laboratory of Public Health (LACEN) in the focal area states ${ }^{6,7}$.

As predators of rodents, dogs and cats can become infected with $Y$. pestis either by infected flea bites or by ingesting infected prey. They develop mild to severe forms of the disease, and, 
after recovery, they produce antibodies that remain detectable for several months. This justifies their use as sentinels/detectors of $Y$. pestis circulation between the rodents/reservoirs in the foci areas $^{8-11}$. In nature, the time of antigen exposure is unknown; thus, it is generally accepted that high proportions of antibodypositive animals with high antibody titers indicate recent plague activity. It is estimated that sampling a few dogs is equivalent to sampling hundreds of rodents in serological surveys to detect anti-plague antibodies ${ }^{12}$.

This study characterized the circulation dynamics and spatial distribution of $Y$. pestis antibodies in dogs and cats in the plague focal areas of the State of Ceará in Northeastern Brazil between 1990 and 2014.

\section{METHODS}

\section{Ethical considerations}

The project was approved by the Research Ethics Committee of the Federal University of Ceará (UFCE), registry CAAE 51371215.2.0000.5054, number 1383310 .

\section{Study design}

The study was conducted using a time series analysis of sero-surveys among domestic carnivores in plague focal areas of Ceará from 1990 to 2014.

\section{Study area}

The study area included 44 (23.9\%) of the state's 184 municipalities, located in seven focal plague areas: Serra de Ibiapaba, Serra de Baturité, Serra da Uruburetama, Serra das Matas; Serra da Pedra Branca, Serra do Machado, and Chapada do Araripe. The total area comprises $29,855 \mathrm{~km}^{2}, 20.4 \%$ of the state's surface ${ }^{6,7}$.

\section{Municipality inclusion criteria}

Municipalities that performed plague serological surveillance of dogs and cats for at least one year between 1990 and 2014 were included in the study. Duplicate records in the Sistema de Informação do Programa de Peste (SISPESTE) were excluded.

\section{Data collection}

Secondary data were collected from Plague Control Program (PCP) reports in Ceará, SISPESTE, and the Plague Regional Laboratory in Fortaleza (CE), from 1990 to 2005 and from LACEN-CE from 2005 to 2014.

The field surveillance program was conducted during annual cycles of health agent visits and blood sample collections from dogs and cats for serological analyses ${ }^{13}$.

\section{Serological analyses}

Passive Hemagglutination Assays/HemagglutinationInhibition (HA/HI) assays were used to detect specific $Y$. pestis anti-F1 antibodies ${ }^{13}$. In brief, the tests were performed using 96-well U-shaped polystyrene plates. Twenty-five microliters of each serum was serially diluted $(1 / 4$ to $1 / 8,192)$ into $25 \mu \mathrm{L}$ of HA buffer containing sterile normal saline (NS) and 1/100 normal rabbit sera (NRS). The sera were simultaneously diluted into the $\mathrm{HI}$ buffer containing $100 \mu \mathrm{g} / \mathrm{mL}$ of F1-specific $Y$. pestis protein antigen suspension, as described above. Next, $25 \mu \mathrm{L}$ of a saline suspension (NS plus 1/250mL NRS) of sheep red blood cells (SRBCs) sensitized with $100 \mathrm{ug} / \mathrm{mL}$ of F1 (SRBCs/ F1) was added to each well. Samples were incubated overnight at $4-10^{\circ} \mathrm{C}$. The test was considered positive when the HA endpoint titer was depressed by three or more dilutions in the HI test. A titer of $\geq 1 / 16$ was considered antibody-positive. The NRS used to prepare the buffers and all sera tests were previously inactivated at $56^{\circ} \mathrm{C}$ for $30 \mathrm{~min}$ in a water-bath and adsorbed for $30 \mathrm{~min}$ at room temperature with fresh sheep red blood cells ${ }^{13}$.

\section{Data analysis}

A database was built using MS Excel 2010 to organize, separate and categorize the information. The data were exported and analyzed using Stata software, version 11.2. Time trend analysis was performed using the Joinpoint Regression Program, version 4.5.0.1. The trend analysis included dog surveillance data from 1997 to 2014, and cat surveillance data from 1997 to 2009. To calculate the annual percentage change (APC) in the antibody-positive animal proportions, a trend analysis was performed using continuous linear regression with inflection points (Joinpoint method). This method allowed the time series data to be adjusted from the minimum number of joinpoints (i.e., 0 joinpoints, which is a straight line) and determined whether the inclusion of more joinpoints was statistically significant. The significance is represented by graphs and two indicators, the APC and the average annual percentage change (AAPC).

The trend analysis of the significant variables from Ceará and for each plague focus was determined. Each significant point that indicated a change in the increase or decrease (if any) was maintained in the final model ${ }^{14}$. The independent variable (Y) was the study year, and the dependent variables (X) were the proportion of antibody-positive dogs, the proportion of antibody-positive cats, and the proportion of antibodypositive animals (dogs and cats). Differences were considered statistically significant at a $p$ value $<0.05$.

The joinpoint analysis was performed using the number of antibody-positive animals as the numerator, and the number of tested animals as the denominator, multiplied by 100 . Data were converted logarithmically. Errors were considered heteroskedastic, and the regression coefficients were estimated by weighted least squares. For both the proportion of antibodypositive animals, and the temporal evaluation of the data, an adjusted autocorrelation model of the errors based on the data was also used.

The APC and the AAPC confidence intervals 95\% (95\% CI) were calculated using the empirical quantile method. This method generates re-sampled data by (i) generating re-sampled residuals as the inverse function values of uniform random numbers over $0 \%$ to $100 \%$, where the function is the empirical distribution function of the original residuals, then (ii) adding resampled residuals to the original fit. A total of 10,000 re-samples were used for the analyses. A maximum of two joinpoints for the periods were considered. 


\section{RESULTS}

From 1997 to 2014, serum samples from 203,311 dogs from seven plague foci in Ceará were analyzed for Y. pestis anti-F1 antibodies using HA-HI testing, and 3,023 (1.49\%) were antibody-positive. Of the serum samples from 61,135 cats analyzed from 1997 to 2009, 426 (0.7\%) were HA-HI-positive (Table 1).

Joinpoint analysis showed two different trends, both for dogs and for cats (Figure 1A, Figure 1B and Figure 1C). The proportion of antibody-positive dogs displayed a nonsignificant positive trend (APC $=10.7,95 \% \mathrm{CI}:-14.2$ to 42.9 , $\mathrm{p}=0.402$ ) in the period of 1997 to 2002. From 2002 to 2014, the trend changed, and the proportion of antibody-positive dogs decreased significantly (APC $=-17.2,95 \%$ CI: -24.6 to -9.1 , $\mathrm{p}<0.001)$. The AAPC for the entire period displayed a significant decreasing trend (AAPC $=-9.8,95 \%$ CI: -18.4 to -4.4) (Table 2 and Figure 1A). Joinpoint analysis showed that the proportion of antibody-positive cats increased significantly from 1997 to 2001 (APC $=40.5,95 \%$ CI: 10.3 to $78.9, p=$ 0.011 ), then decreased significantly from 2001 to 2009 (APC
$=-29.1,95 \%$ CI: -35.6 to $-22.1, \mathrm{p} \leq 0.001)$. The AAPC for the entire period displayed an overall downward trend, but the model was not statistically significant $(\mathrm{AAPC}=-11.0,95 \% \mathrm{CI}$ : -38.1 to 3.4) (Table 2 and Figure 1B).

In the accumulated period from 1997 to 2014, 16 (36.4\%) municipalities had up to 25 antibody-positive dogs, 19 (43.2\%) had 25 to 100 , five $(11.4 \%)$ had 100 to 200 , and four $(9 \%)$ municipalities had over 400 antibody-positive dogs. Over the years, both antibody-positive dogs per locality and the number of localities with antibody-positive dogs decreased. Therefore, after 2003, no municipality had more than 40 antibody-positive dogs. The number antibody-positive cats per municipality also decreased, as did the number of municipalities with antibody-positive cats. Throughout the entire study period, 11 (25\%) municipalities had no antibody-positive cats, 15 (34\%) had up to five antibodypositive cats, $10(22 \%)$ had five to 15 , six (14\%) had 15 to 40 and two $(5 \%)$ municipalities had 40 to 140 antibody-positive cats.

The median proportion of antibody-positive dogs was higher in the foci of Chapada do Araripe (0.87), followed by Serra do Machado (0.85) and Serra Uruburetama (0.81). The highest proportion was found in Serra das Matas (3.33)

TABLE 1: Distribution of antibody-positive dogs and cats from the plague foci in Ceará from 1997 to 2014.

\begin{tabular}{|c|c|c|c|c|c|c|}
\hline \multirow[b]{2}{*}{ Year } & \multicolumn{3}{|c|}{ Dogs } & \multicolumn{3}{|c|}{ Cats* } \\
\hline & tested & positives & $\begin{array}{l}\text { proportion of } \\
\text { positives }\end{array}$ & tested & positives & $\begin{array}{l}\text { proportion of } \\
\text { positives }\end{array}$ \\
\hline 1997 & 8,367 & 417 & 4.98 & 5,970 & 67 & 1.12 \\
\hline 1998 & 10,191 & 45 & 0.44 & 6,469 & 17 & 0.26 \\
\hline 1999 & 10,491 & 131 & 1.25 & 6,132 & 31 & 0.51 \\
\hline 2000 & 8,714 & 65 & 0.75 & 4,991 & 6 & 0.12 \\
\hline 2001 & 9,581 & 378 & 3.95 & 4,995 & 170 & 3.40 \\
\hline 2002 & 6,581 & 313 & 4.76 & 3,596 & 30 & 0.83 \\
\hline 2003 & 9,096 & 183 & 2.01 & 5,159 & 23 & 0.45 \\
\hline 2004 & 9,466 & 176 & 1.86 & 4,640 & 16 & 0.34 \\
\hline 2005 & 11,135 & 387 & 3.48 & 4,535 & 28 & 0.62 \\
\hline 2006 & 12,261 & 139 & 1.13 & 4,362 & 7 & 0.16 \\
\hline 2007 & 13,258 & 207 & 1.56 & 5,137 & 19 & 0.37 \\
\hline 2008 & 12,153 & 125 & 1.03 & 4,689 & 11 & 0.23 \\
\hline 2009 & 14,342 & 109 & 0.76 & 460 & 1 & 0.22 \\
\hline 2010 & 14,586 & 51 & 0.35 & - & - & - \\
\hline 2011 & 14,005 & 109 & 0.78 & - & - & - \\
\hline 2012 & 12,476 & 63 & 0.50 & - & - & - \\
\hline 2013 & 13,257 & 69 & 0.52 & - & - & - \\
\hline 2014 & 13,351 & 56 & 0.42 & - & - & - \\
\hline Total & 203,311 & 3,023 & 1.49 & 61,135 & 426 & 0.70 \\
\hline
\end{tabular}

*Surveillance of cats was discontinued after 2009. 


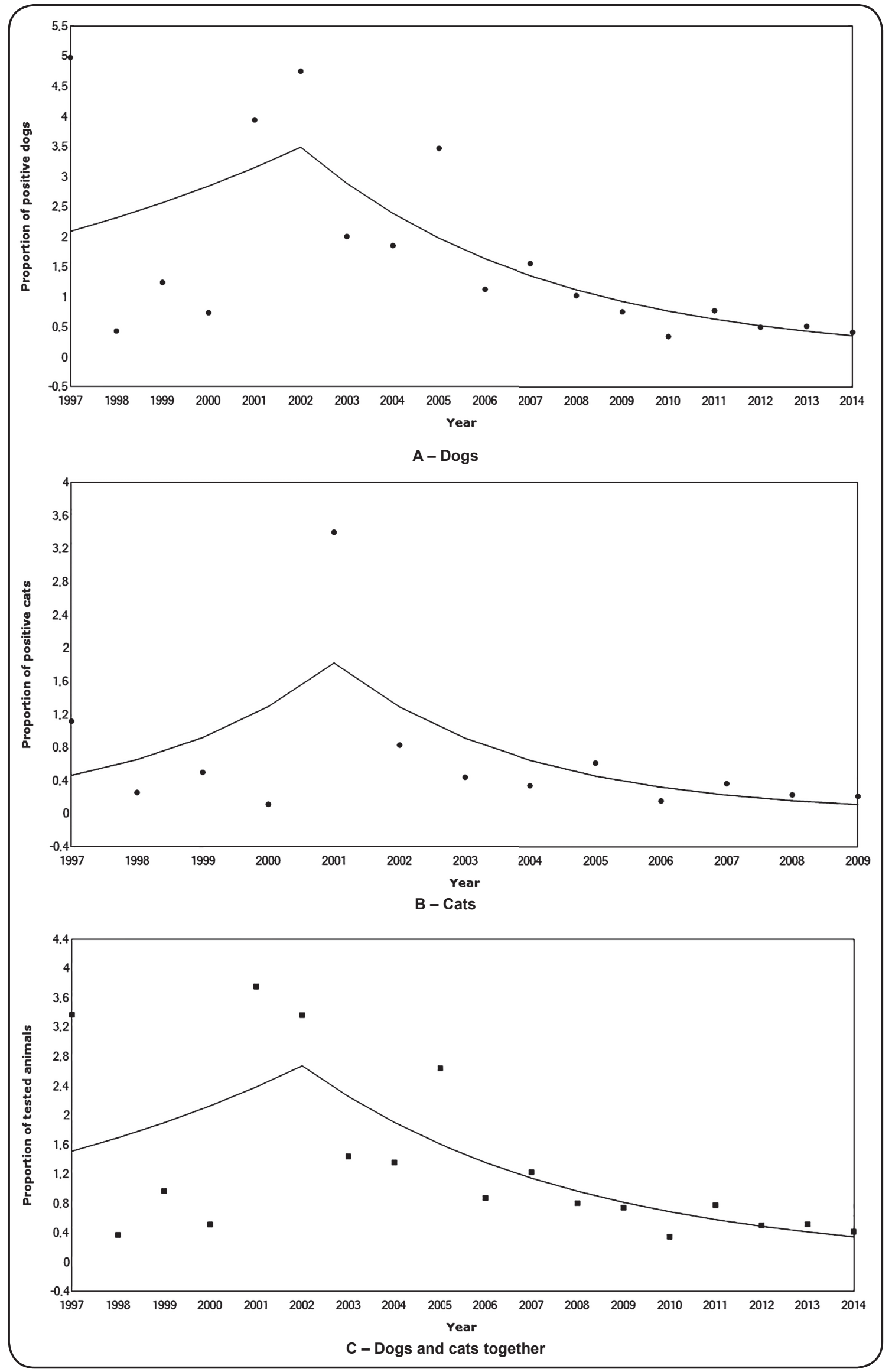

FIGURE 1 - Temporal trends of the proportion of antibody-positive: A: dogs, B: cats, and C: dogs and cats together, from the plague foci in Ceará from 1997 to 2014, using joinpoint analysis. 
TABLE 2: Joinpoint regression analysis of the proportion of positive animals in Ceará from 1997-2014 (dogs, and dogs and cats together) and from 1997-2009 (cats).

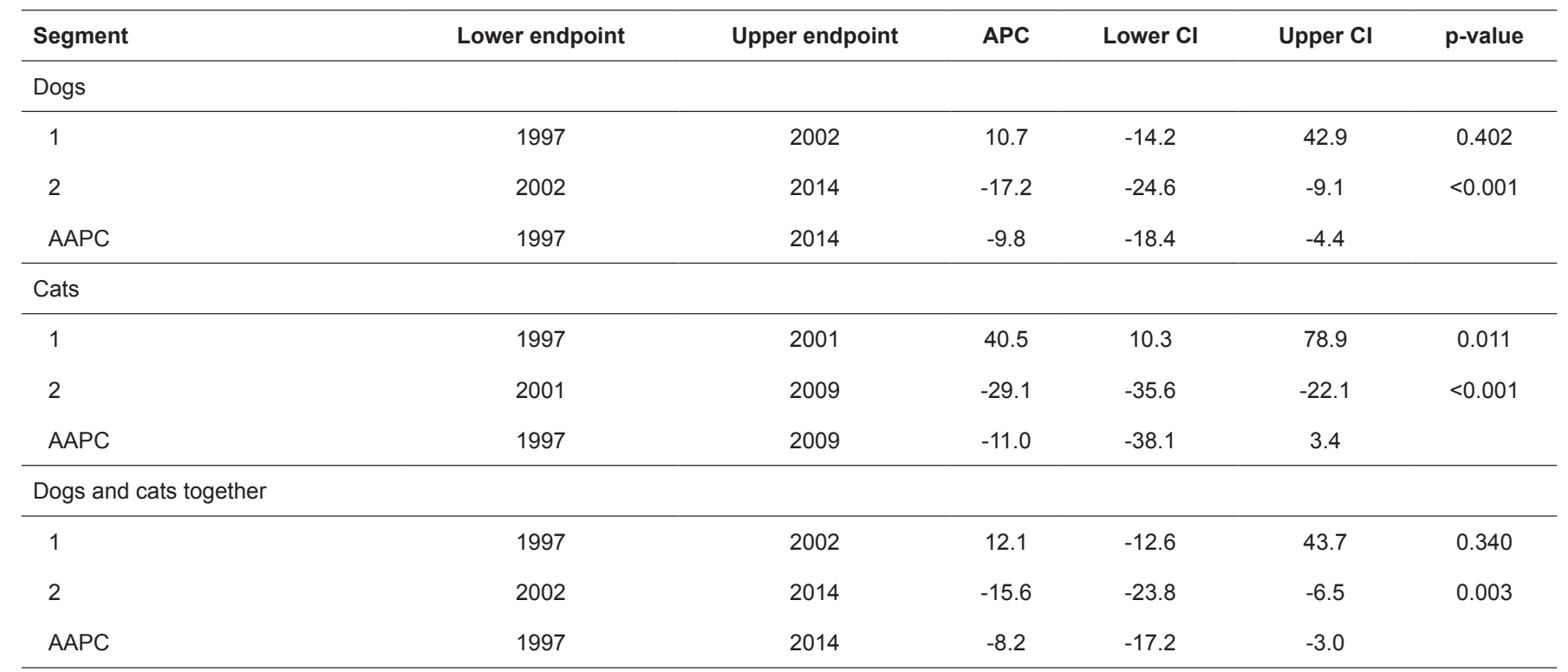

APC: annual percentage change; $\mathbf{C l}$ : confidence interval; AAPC: average annual percentage change.

(Table 3). During the study period, the proportion of infected dogs decreased over time in the seven plague foci. However, there was a notably high proportion of antibody-positive dogs in Serra do Machado almost every year (Table 4).

Regarding the HA/HI titer distribution in the historical series from 1990 to 2014, a total of 3,631 dogs and cats had anti-plague antibodies, with titers ranging from $1 / 16$ to $1 / 8,192$. The most frequent titers were $1 / 32(\mathrm{n}=1,100$ animals $), 1 / 64$ $(\mathrm{n}=997)$ and $1 / 16(\mathrm{n}=916)$, representing $30 \%, 27 \%$ and $25 \%$ of the total, respectively. The highest titers were less frequent or rare: $1 / 128(\mathrm{n}=290) 1 / 256(\mathrm{n}=154), 1 / 512(\mathrm{n}=148), 1 / 1$ $1,024(\mathrm{n}=15), 1 / 2,048(\mathrm{n}=8), 1 / 4,096(\mathrm{n}=2)$ and $1 / 8,192$ $(\mathrm{n}=1)$. This may be due to the laboratory routine, which usually tests up to 6 dilutions (1/128) and only occasionally up to 12 dilutions $(1 / 8,192)$.

\section{DISCusSION}

Dogs and cats participate in the epidemiological cycle of the plague and are good indicators of infection activity in the focal areas. They can carry infected rodents and fleas to human premises, thus increasing the risk of human infection ${ }^{15}$.

Dogs in highly enzootic areas may be repeatedly exposed to plague-infected rodents and fleas and develop high Y. pestis antibody titers ${ }^{16}$. In China, serological surveys of dogs are an important tool for plague surveillance, as these animals are notable plague carriers ${ }^{17}$.

TABLE 3: Minimum, median, and quartiles of the proportion of antibody-positive dogs in Ceará from 2008 to 2014.

\begin{tabular}{|c|c|c|c|c|c|}
\hline Foci & Minimum & $1^{\text {st }}$ Quartile & Median & $3^{\text {rd }}$ Quartile & Maximum \\
\hline Chapada do Araripe & 0.31 & 0.35 & 0.87 & 1.01 & 1.47 \\
\hline Serra da Pedra Branca & 0.26 & 0.29 & 0.43 & 0.63 & 0.8 \\
\hline Serra de Baturité & 0.32 & 0.35 & 0.5 & 1.11 & 1.54 \\
\hline Serra de Uruburetama & 0.23 & 0.29 & 0.81 & 1.05 & 1.34 \\
\hline Serra do Machado & 0 & 0.54 & 0.85 & 1.26 & 1.77 \\
\hline
\end{tabular}


TABLE 4: Distribution of the proportion of antibody-positive dogs from the plague foci in Ceará from 2008-2014.

\begin{tabular}{|c|c|c|c|c|c|c|c|c|}
\hline \multirow{2}{*}{ Year } & \multicolumn{7}{|c|}{ Plague foci } & \multirow{2}{*}{$\begin{array}{l}\text { Ceará } \\
\text { State }\end{array}$} \\
\hline & $\begin{array}{c}\text { Chapada do } \\
\text { Araripe }\end{array}$ & $\begin{array}{l}\text { Serra da } \\
\text { lbiapaba }\end{array}$ & $\begin{array}{c}\text { Serra da Pedra } \\
\text { Branca }\end{array}$ & $\begin{array}{l}\text { Serra das } \\
\text { Matas }\end{array}$ & $\begin{array}{l}\text { Serra de } \\
\text { Baturité }\end{array}$ & $\begin{array}{c}\text { Serra de } \\
\text { Uruburetama }\end{array}$ & $\begin{array}{l}\text { Serra do } \\
\text { Machado }\end{array}$ & \\
\hline 2008 & 0.87 & 1.02 & 0.80 & 3.33 & 1.11 & 1.34 & 1.77 & 1.03 \\
\hline 2009 & 1.47 & 0.45 & 0.26 & 1.52 & 1.54 & 1.05 & 0.85 & 0.76 \\
\hline 2010 & 0.31 & 0.34 & 0.29 & 0.00 & 0.35 & 0.44 & 0.54 & 0.35 \\
\hline 2011 & 0.98 & 0.65 & 0.43 & 0.70 & 0.76 & 0.93 & 1.26 & 0.78 \\
\hline 2012 & 1.01 & 0.48 & 0.43 & 0.90 & 0.48 & 0.29 & 0 & 0.50 \\
\hline 2013 & 0.35 & 0.51 & 0.63 & 0.23 & 0.50 & 0.81 & 1.18 & 0.52 \\
\hline 2014 & 0.53 & 0.48 & 0.48 & 0.41 & 0.32 & 0.23 & 0.59 & 0.42 \\
\hline Total & 0.75 & 0.57 & 0.46 & 0.56 & 0.67 & 0.59 & 0.78 & 0.62 \\
\hline
\end{tabular}

All animals in our study were domesticated, living in direct contact with humans. In the rural areas included in this study, dogs are commonly used for hunting, and cats help to control the rodents in homes, and in grain and food storage buildings. Therefore, they are exposed to $Y$. pestis through contact with rodents and their fleas.

The historical time series analysis in our study revealed similar trends for both positive dogs and cats, with a reduction in positivity from 2001 among cats and from 2002 among dogs. The proportion of positive dogs increased from 1997 to 2002 (not significantly) and declined significantly from 2002 to 2014. Among the cats, the trend increased from 1997 to 2001 and decreased from 2001 to 2009 , both being statistically significant (Table 2, Figure 1A, Figure 1B and Figure 1C).

The human plague prevalence has also declined in the Ceará plague foci since the $1990 \mathrm{~s}^{7}$. Our findings corroborate those of other studies on temporal associations with human plague incidence ${ }^{18-20}$. Parmenter et al. ${ }^{21}$ found that the cyclical pattern of the annual distribution of plague cases in New Mexico (USA) was associated with fluctuations in the rodent population or in the rodents' responses to environmental variations such as food and shelter availability.

During our study period, the prevalence of antibody-positive dogs was $1.49 \%(3,023 / 203,311)$, with more than $4 \%$ antibodypositivity in 1997 and 2002, and the overall prevalence for cats was $0.70 \%(426 / 61,135)$, with higher antibody-positivity (3.40\%) in 2001 (Table 1). Previous studies found that antibodypositivity prevalence among dogs and cats from the Ceará plague foci, and from Chapada da Borborema (PB), were similar ${ }^{13,22}$. During a plague outbreak in a village in Yunnan Province, China serum-positivity rates in domestic cats and dogs were $23.5 \%$ and $26.5 \%$, respectively ${ }^{23}$. This could be because many diseased cats do not survive the infection, while dogs are more resistant and more likely to recover ${ }^{10}$.

Because it was assumed that plague antibody detection is more sensitive in dogs than in cats and rodents, the plague surveillance of cats was discontinued in the Brazilian foci $\operatorname{areas}^{24}$. Despite the low antibody-positive prevalence $(<1 \%)$ during the study period (with the exception of 1997 and 2001), cats tested antibody-positive in all years investigated. Therefore, serological surveillance in cats should not be discontinued, as it may be valuable for the plague monitoring program. Almeida et al. ${ }^{22}$ recorded $76 \%$ positive samples from cats, and $49.1 \%$ from dogs in Serra de Baturité (CE) during a human plague outbreak. The high positivity among cats was likely due to animals being infected and then surviving the disease during those events. Therefore, to improve the monitoring of $Y$. pestis in plague areas, implementing surveillance for cats is recommended.

In the USA, serological surveillance is performed on a wide variety of mammals, as it is thought that this procedure is more sensitive, and allows better assessment of plague behavior and circulation in focal areas ${ }^{25-26}$. Lowell et al. ${ }^{27}$ state that surveillance involving many species provides better coverage of plague activity than monitoring a single species. Plague surveillance programs monitoring die-offs and serum prevalence in reservoir animal populations can provide an early and timely warning of possible human cases $^{10,27}$.

In the surveillance routine of sentinel animals, including coyotes (Canis latrans), badgers (Taxidea taxus), and raccoons (Procyon lotor) in American plague areas, an overall prevalence of $16 \%(3,481 / 21,826)$ was found, varying by region and species. The prevalence rate was higher in mustelids $(43 \%$ $504 / 1,173)$, followed by bears $(23 \%-95 / 459)$ and canids $(15 \%$ $-1,079 / 7,291)^{28}$. Malmlov et al. reported a $28 \%(7 / 25)$ serum prevalence in coyotes ${ }^{26}$.

Despite the reduction in antibody-positive dogs per municipality, the number of municipalities with antibodypositive animals increased, and after 2003, the number of municipalities with antibody-positive dogs also increased. These results suggest that the infection is spreading geographically (i.e. few animals dispersed over larger areas). This change could 
result from eco-epidemiological factors favoring dissemination, such as the densities of natural vectors and rodent hosts, in addition to possible climatic changes, such as temperature and precipitation ${ }^{19}$. Comparing the proportional distribution of antibody-positive dogs in the seven plague foci, the prevalence was reduced in all but Pedra Branca, where antibody-positivity was instead increased. Serra do Machado had the highest prevalence in dogs during the study period.

Analyzing the focal associations, statistically significant correlations were found between Serra da Uruburetama and the year; Chapada do Araripe and Serra das Matas; Serra de Ibiapaba, Serra da Pedra Branca and Serra do Machado; Serra de Baturité and Serra de Uruburetama and between Serra de Uruburetama and Serra do Machado (Table 3 and Table 4). The prevalence rates among the different plague focal areas may have been influenced by factors common to the seven foci. Thus, we assume a common pattern exists for actively circulating $Y$. pestis in the focal areas. These results agree with those of Baltazard $^{29}$, who considered that the geographical massifs of Ibiapaba, Baturité, Machado, Uruburetama, Pedra Branca and Matas constitute a single focus. Giles et al. ${ }^{30}$ confirmed that plague is focal in northeast Brazil, with a discontinuous distribution. These studies showed that those foci depend on a broad set of conditions, and are not necessarily correlated with their elevation, but likely to the presence of the hairy-tailed bolo mouse, Necromys lasiurus, which is the primary plague host in these foci, and is responsible for epizootics.

The proportion of antibody-positive animals fluctuated in all foci, however, these fluctuations were only statistically significant in Serra das Matas. A prevalence higher than $1 \%$ was observed in some years, which increases the risk for human cases to emerge ${ }^{12}$.

Antibody titers among dogs and cats in the study period showed a higher frequency of $1 / 32$, followed by $1 / 64$ and $1 / 16$. Titers $\geq 1 / 64$ suggest recent infections and recent contact with Y. pestis, signaling a potential risk for human infection ${ }^{12-13,22}$. Paul-Murphy et al. ${ }^{31}$ reported anti- $Y$. pestis antibody titers $\geq 1 / 128$ in 15 pumas, Felis concolor, and a range of 1/1,024 to $1 / 4,096$ in four pumas in rural areas of California (USA). In coyotes from urban areas in California, titers ranged from 1/16 to $1 / 1,024^{26}$. In plague areas of China, titers varying from $1 / 40$ to $1 / 1,280$ were found in 49 domestic dogs ${ }^{23}$.

In conclusion, during the study period, the prevalence of antibody-positive dogs and cats fluctuated, with a significant reduction in recent years. However, our results also revealed annual antibody-positive animals, providing evidence that $Y$. pestis is persisting in active circulation. Thus, even the quiescent areas with no human cases have the potential for transmission risk, and despite the decrease in antibody-positive domestic carnivores, continual surveillance is needed in these areas. Due to the plague's cyclical characteristics - alternating periods of activity and quiescence depending on a series of complex factors - plague can reemerge and reach the human population. Hence, surveillance, monitoring, and control actions must be continued.

\section{Acknowledgements}

We would like to thank the Secretaria da Saúde do Estado do Ceará (SESA), Núcleo de Controle de Vetores (NUVET) and Laboratório Central de Saúde Pública (LACEN)

\section{Conflicts of interest}

The authors declare that there is no conflict of interest.

\section{REFERENCES}

1. Butler T. Plague gives surprises in the first decade of the $21^{\text {st }}$ century in the United States and worldwide. Am J Trop Med Hyg. 2013;89(4):788-93.

2. Butler T. Plague history: Yersin's discovery of the causative bacterium in 1894 enabled, in the subsequent century, scientific progress in understanding the disease and the development of treatments and vaccines. Clin Microbiol Infect. 2014;20(3):202-9.

3. World Health Organization (WHO). Plague around the world, 20102015. Wkly Epidemiol Rec. 2016;91(8):89-104.

4. Stenseth NC, Atshabar BB, Begon M, Belmain SR, Bertherat E, Carniel E, et al. Plague: past, present and future. PLoS Med. 2008;5(1):e3.

5. World Health Organization (WHO). International Health Regulations (2005). $2^{\text {nd }}$ edition Geneva: WHO; 2008. 74p.

6. Tavares C, Aragão AI, Leal NC, Leal-Balbino TC, de Oliveira MB, de Oliveira GFGM, et al. Plague in Brazil: from now and then. Adv Exp Med Biol.2012;954:69-77.

7. Aragão AI, Pontes RJS, Seoane ACM, Nascimento OJ, Tavares C, Almeida AMP. Tendência secular da peste no Estado do Ceará, Brasil. Cad Saúde Pública. 2007;23(3):715-24.

8. Rust Jr JH, Cavanaugh DC, O'Shita R, Marshall Jr JD. The role of domestic animals in the epidemiology of plague, I: Experimental infection of dogs and cats. J Infect Dis. 1971;124(5):522-6.

9. Rust Jr JH, Miller BE, Bahamnyar M, Marshall Jr JD, Purnaveja $\mathrm{S}$, Cavanaugh $\mathrm{DC}$, et al. The role of domestic animals in the epidemiology of plague. II. Antibody to Yersinia pestis in sera of dogs and cats. J Infect Dis. 1971;124(5):527-31.

10. Barnes AM. Surveillance and control of bubonic plague in the United States. Symp Zool Soc Lond. 1982;50:237-70.

11. Gasper PW, Barnes AM, Quan TJ, Benziger JP, Carter LG, Beard ML, et al. Plague (Yersinia pestis) in cats: description of experimentally induced disease. J Med Ent. 1993;30(1):20-6.

12. Dennis DT, Gage KL, Gratz N, Poland JD, Tikhomirov E. Plague manual: epidemiology, distribution, surveillance and control. Geneva: World Health Organization. 1999. Available from: www. who.int/csr/resources/publications/plague/WHO.../en]

13. Aragão AI, Pinheiro KMA, Seoane ACM, Tavares C, Almeida AMP. Prevalência de anticorpos contra Yersinia pestis em carnívoros domésticos nos focos pestosos do Estado do Ceará. Rev Soc Bras Med Trop. 2009;42(6):711-5.

14. Kim HJ, Fay MP, Feuer EJ, Midthune DM. Permutation tests for joinpoint regression with applications to cancer rates. Stat Med. 2000;19(3):335-51.

15. Gage KL. Factors affecting the spread and maintenance of plague. In: Almeida AMP, Leal NC, editors. Advances in Yersinia Research. New York: Springer Science Business Media. 2012. p. 79-94.

16. Gould LH, Pape J, Ettestad P, Griffith KS, Mead PS. Dog-associated risk factors for human plague. Zoonoses and Public Health. 2008;55(8-10):448-54. 
17. Li B, Guo Y, Guo Z, Liang Y, Zhu Z, Zhou Q, et al. Serologic survey of the sentinel animals for plague surveillance and screening for complementary diagnostic markers to $\mathrm{F} 1$ antigen by protein microarray. Am J Trop Med Hyg. 2008;79(5):799-802.

18. Enscore RE, Biggerstaff BJ, Brown TL, Fulgham RF, Reynolds PJ, Engelthaler DM, et al. Modeling relationships between climate and the frequency of human plague cases in the southwestern United States, 1960-1997. The Am J Trop Med Hyg. 2002;66(2):186-96.

19. Ben Ari T, Gershunov A, Gage KL, Snall T, Ettestad P, Kausrud $\mathrm{KL}$, et al. Human plague in the USA: the importance of regional and local climate. Biol Lett. 2008;4(6):737-40.

20. Kreppel KS, Caminade C, Telfer S, Rajerison M, Rahalison L, et al. A non-stationary relationship between global climate phenomena and human plague incidence in Madagascar. PLoS Negl Trop Dis. 2014;8(10):e3155.

21. Parmenter RR, Yadav EP, Parmenter CA, Ettestad P, Gage KL. Incidence of plague associated with increased winter-spring precipitation in New Mexico, Am J Trop Med Hyg. 1999;61(5): 814-21.

22. Almeida AMP, Brasil DP, Melo MEB, Leal NC, Almeida CR. Importância dos carnívoros domésticos (cães e gatos) na epidemiologia da peste nos focos do Nordeste do Brasil. Cad Saúde Pública. 1998;4(1):49-55.

23. Wang H, Cui Y, Wang Z, Wang X, Guo Z, Yan Y, et al. A dogassociated primary pneumonic plague in Qinghai Province, China. Clin Infect Dis. 2011;52(2):185-90.
24. Costa ECV, Sobreira M, Leal NC, Almeida AMP. Rodents and other small mammal reservoirs in plague foci in northeastern Brazil. J Infect Dev Ctries. 2017;11(5):426-30.

25. Gage KL, Kosoy MY. Natural history of plague: perspectives from more than a century of research. Annu Rev Entomol. 2005;50: 505-28.

26. Malmlov A, Breck S, Fry T, Duncan C. Serologic survey for crossspecies pathogens in urban coyotes (Canis latrans), Colorado, USA. J Wildl Dis. 2014;50(4):946-50.

27. Lowell JL, Eisen RJ, Schotthoefer AM, Xiaocheng L, Montenieri JA, Tanda D, et al. Colorado animal-based plague surveillance systems: relationships between targeted animal species and prediction efficacy of areas at risk for humans. J Vector Ecol. 2009;34(1):22-31.

28. Salkeld DJ, Stapp P. Seroprevalence rates and transmission of plague (Yersinia pestis) in mammalian carnivores. Vector Borne Zoonotic Dis. 2006;6(3):231-9.

29. Baltazard M. Research on plague in Brazil. Bull Soc Pathol Exot. 2004;T97:93-117.

30. Giles J, Peterson AT, Almeida A. Ecology and geography of plague transmission areas in Northeastern Brazil. PLoS Negl Trop Dis. 2011;5(1) e925.

31. Paul-Murphy J, Work T, Hunter D, McFie E, Fjelline D. Serologic survey and serum biochemical reference ranges of the freeranging mountain lion (Felis concolor) in California. J Wildl Dis. 1995;30(2):205-15. 